\title{
THE NANOSATC-BR, CUBESAT DEVELOPMENT PROGRAM - A JOINT CUBESAT PROGRAM DEVELOPED BY UFSM AND INPE/MCTIC - SPACE GEOPHYSICS MISSION PAYLOADS AND FIRST RESULTS
}

\author{
Nelson J. Schuch ${ }^{1}$, Otávio S. C. Durão², Marlos R. da Silva², Fátima Mattiello-Francisco², \\ João B. dos S. Martins ${ }^{3}$, Andrei P. Legg ${ }^{3}$, André L. da Silva ${ }^{3}$ and Eduardo E. Bürguer ${ }^{3}$
}

\begin{abstract}
The INPE-UFSM's NANOSATC-BR, CubeSats Development Program started in 2008. Currently, the Program counts with two CubeSats: the NANOSATC-BR1 (1U) launched in 2014 and still in operation \& the NANOSATC-BR2 (2U), under development, which is expected to be launched in the last quarter of 2019. In this article, the scientific and technological results of the NANOSATC-BR1 and the finalization of NANOSATC-BR2 are presented. Considering the Capacity Building, the major target of the Program, the paper emphasizes the involvement of Universidade Federal de Santa Maria - UFSM undergraduate/graduate students in the conception, development and operation of NANOSATC-BR1, as well as the participation of the Instituto Nacional de Pesquisas Espaciais - INPE graduate students in the on-board data handling $(\mathrm{OBDH})$ software subsystem development, verification and validation for the NANOSATC-BR2. In addition, the collaborations of other Space Science, Engineering and Computer Science institutions involved in Brazil and abroad are discussed. The Program has received financial support from the Brazilian Space Agency (Agência Espacial Brasileira - AEB) and the Ministry of Science, Technology, Innovation and Communications (MCTIC).
\end{abstract}

Keywords: CubeSats, nanosatellites, capacity building.

RESUMO. 0 programa NANOSATC-BR, Desenvolvimento de CubeSats, parceria INPE - UFSM, teve início em 2008. Atualmente, o Programa conta com dois CubeSats: o NANOSATC-BR1 (1U), lançado em 2014 e ainda em operação, e o NANOSATC-BR2 (2U), que está em desenvolvimento e tem expectativa de lançamento no último trimestre de 2019. Nesse artigo, a finalização do desenvolvimento do NANOSATC-BR2 e os resultados científicos e tecnológicos do NANOSATC-BR1 são apresentados. Considerando a Capacitação Profissional, o maior objetivo do Programa, o artigo dá ênfase ao envolvimento dos alunos de graduação da Universidade Federal de Santa Maria (UFSM) na concepção, desenvolvimento e operação do NANOSATC-BR1, ao mesmo tempo em que enfatiza a participação dos alunos de pós-graduação do Instituto Nacional de Pesquisas Espaciais (INPE) no desenvolvimento, verificação e validação do Subsistema de Computador de Bordo para 0 NANOSATC-BR2. Além disso, colaborações de outras instituições de Ciência Espacial, Engenharia e institutos de computação aplicada do Brasil e exterior, são igualmente discutidas. 0 Programa recebeu suporte financeiro da Agência Espacial Brasileira (AEB) e do Ministério da Ciência, Tecnologia, Inovações e Comunicações (MCTIC).

Palavras-chave: CubeSats, nanosatélites, formação de recursos humanos.

\footnotetext{
${ }^{1}$ Instituto Nacional de Pesquisas Espaciais, Centro Regional Sul de Pesquisas Espaciais - CRS/COCRE/INPE-MCTIC, Santa Maria Space Science Laboratory LACESM/CT-UFSM, Santa Maria, RS, Brazil - E-mail: njschuch@gmail.com

${ }^{2}$ Instituto Nacional de Pesquisas Espaciais - INPE/MCTIC, São José dos Campos, SP, Brazil - E-mails: otavio.durao@inpe.br, marlos.silva@inpe.br, fatima.mattiello@inpe.br

${ }^{3}$ Universidade Federal de Santa Maria - UFSM, Technology Center, Santa Maria, RS, Brazil - E-mails: batista@inf.ufsm.br, andrei.legg@gmail.com, andre.silva@ufsm.br, eduardoebrg@gmail.com
} 


\section{INTRODUCTION}

The NANOSATC-BR, CubeSat Development Program, consists of a Brazilian INPE-UFSM Capacity Building Program on space science, engineering and computer sciences for the development of space technologies based in the CubeSat standard, which started with the first Brazilian Scientific Nanosatellite: the NANOSATC-BR1. The Capacity Building Program was conceived at the Southern Regional Space Research Center (Centro Regional Sul de Pesquisas Espaciais - CRS), from the Brazilian National Institute for Space Research (Instituto Nacional de Pesquisas Espaciais - INPE/MCTIC), where acts the Program's General Coordinator and Manager, with technical collaboration and management of the Mission's General Coordinator for Engineering and Space Technology at INPE's Headquarter (HQ), in São José dos Campos, São Paulo. The Program has the involvement of undergraduate students from the Universidade Federal de Santa Maria - UFSM and graduate students from INPE/MCTIC, ITA/DCTA/CA-MD and UFRGS.

This article explains the Program institutional arrangement and the technical characteristics of the satellites and their missions. The Program has support from the Brazilian Space Agency (Agência Espacial Brasileira - AEB) and from the Ministry of Science, Technology, Innovation and Communications MCTIC

\section{NANOSATC-BR: CAPACITY BUILDING}

The major objective of the INPE-UFSM's NANOSATC-BR, CubeSats Development Program, through the NANOSATC-BR1 \& NANOSATC-BR2 CubeSats Projects, is to perform a Specialized Human Resource Capacity Building Program through the training of UFSM's undergraduate students, through Science, Technological \& Innovation Initiation at INPE/MCTIC, in the main areas of Engineering, Computer Sciences and Physics.

Students have an important weight on the Project's technical and scientific branches, since their tasks provide results for each subsystem. The results are consequence of their hard work developed in conjunction with the UFSM's and INPE's specialists (Engineers, Technologists and Researchers), which are the main providers of information.

The brand new Laboratory of Integration and Tests of Nanosatellites (LITN), established at INPE - CRS in the end of 2017, provides an unique environment for students to perform hands on training, by the usage of the Engineering Model of the first satellite of the Program: the NANOSATC-BR1 (or NCBR1). LITN provides to students the adequate tools to perform basic Assembly and Integration operations on a CubeSat Platform, as well as basic Tests, that is, ATT - Assembly, Integration and Tests, with the equipment from the Ground Station (GS), which is now fully integrated to the LITN workbench (Fig. 1).

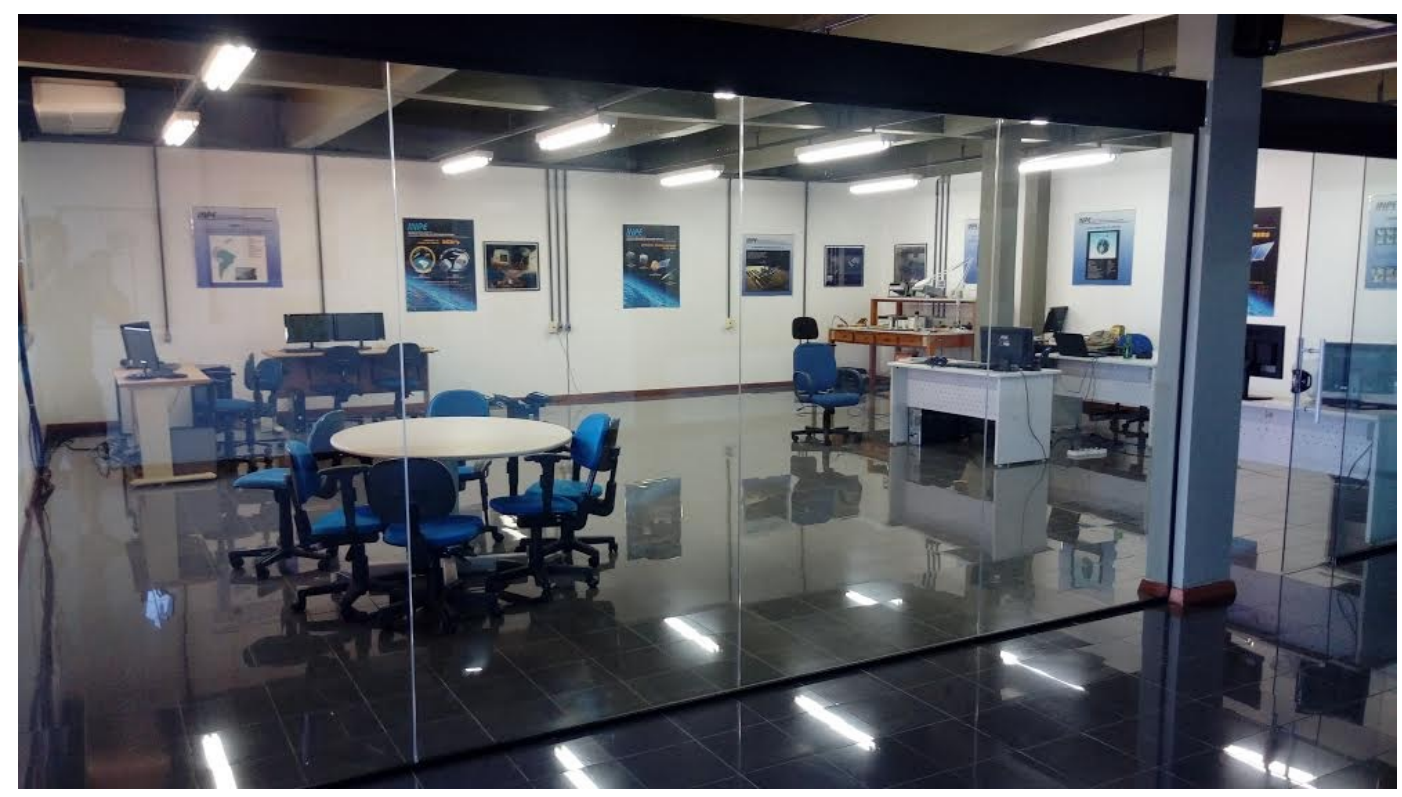

Figure 1 - The Santa Maria Ground Station Control Room (GS) and the Laboratory of Integration and Tests of Nanosatellites (LITN) integrated at the CRS/COCRE/INPE - MCTIC, in Santa Maria, RS, Brazil. 


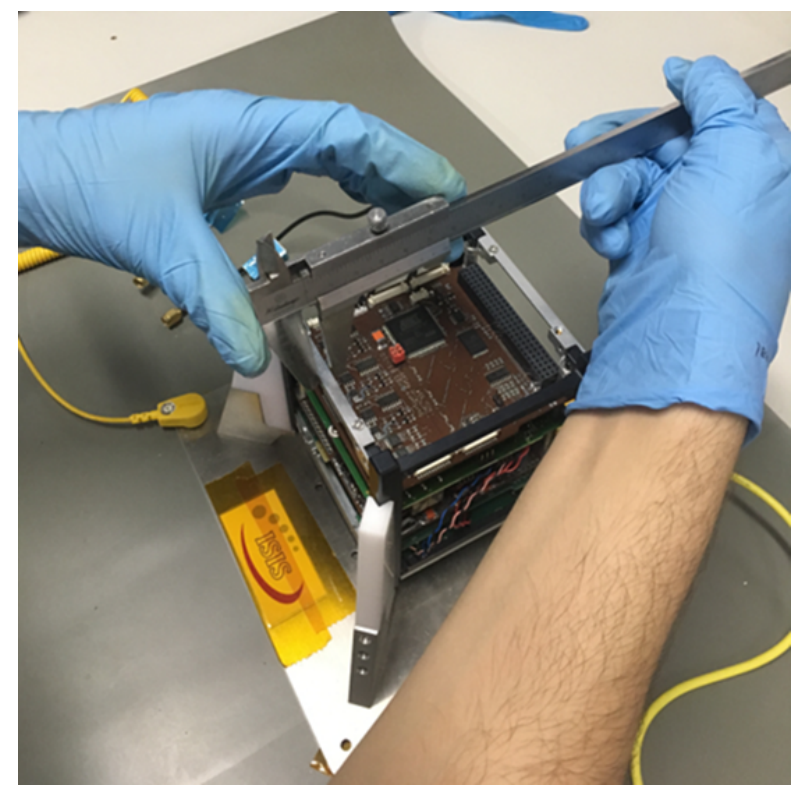

Figure 2 - Aerospace and others Engineering student at LITN using a caliper to perform measurements in a CubeSat.

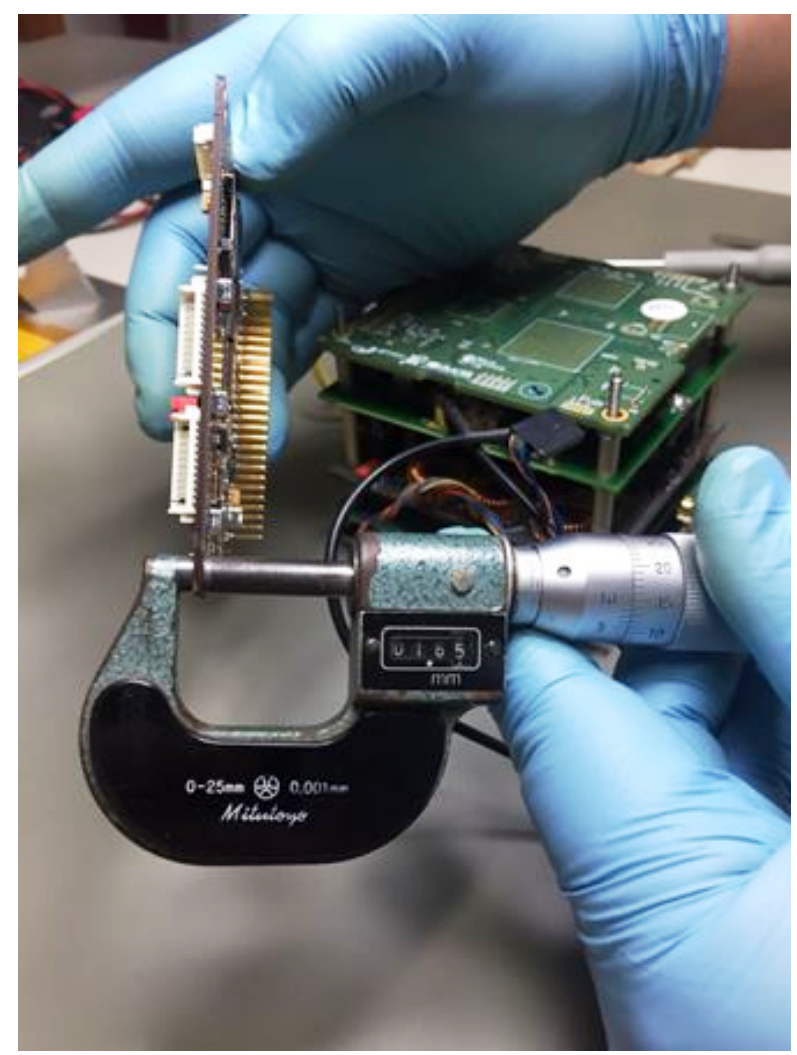

Figure 3 - Electrical Engineering student at LITN using a micrometer to evaluate the thickness of a PCB.
Students from the new Aerospace Engineering and others Engineering courses at the Universidade Federal de Santa Maria (UFSM) can now use instruments, such as calipers (Fig. 2) and micrometers (Fig. 3), at LITN, in order to correctly evaluate mechanical and mass properties of satellite components.

Through the NANOSATC-BR Program, it was possible to approximate the Brazilian Space Program to universities, such as: UFSM, UFRGS, UFRN, UFABC, UFMG and USP. Therefore, the Program provides hands-on training and learning with Aerospace Engineering \& Technologies and Space Weather issues.

Students also had the opportunity to perform further training at universities and space industries abroad: University of Würzburg and German Aerospace Center (DLR) - Germany; Innovative Solutions In Space (ISIS) - The Netherlands; Sapienza Università di Roma - Italy; University at Buffalo, University of Tennessee and NASA - Goddard Space Flight Center - USA. Funding came from several institutions, such as the CubeSat Dutch company Innovative Solutions in Space (ISIS), the Van Allen Project-NASA, the Brazilian Space Agency (AEB) and the Brazilian Program Science without Borders (SwB).

\section{NANOSATC-BR: MISSIONS}

The Program already consists of two CubeSats, the NANOSATC-BR1 and NANOSATC-BR2 (Fig. 4) and has the possibility of launching three other CubeSats in the next five years, operating them in space for at least 6 months each. These new missions aim to study and monitor the Geospace and Space Weather.

The NANOSATC-BR1 concept was developed to: i) monitor, in real time, the Geospace, the disturbances at the Earth's Magnetosphere over the Brazilian territory, and ii) the determination of their effects on regions such as the South America Magnetic Anomaly (SAMA). Its payloads are:

- A XEN-1210 three-axis magnetometer with a resolution of $15 \mathrm{nT}$ from the Dutch company XI - Xensor Integration (www.xensor.nl);

- One board has the magnetometer, which is the scientific payload. It is responsible to measure the perturbations associated with the SAMA.

The NANOSATC-BR1 Technological Mission carries a FPGA (Guareschi et al., 2010) and one integrated circuit (IC) designed by the Santa Maria Design House (SMDH), together with the Graduate Program in Microelectronics from UFRGS (Universidade Federal do Rio Grande do Sul), that were developed 


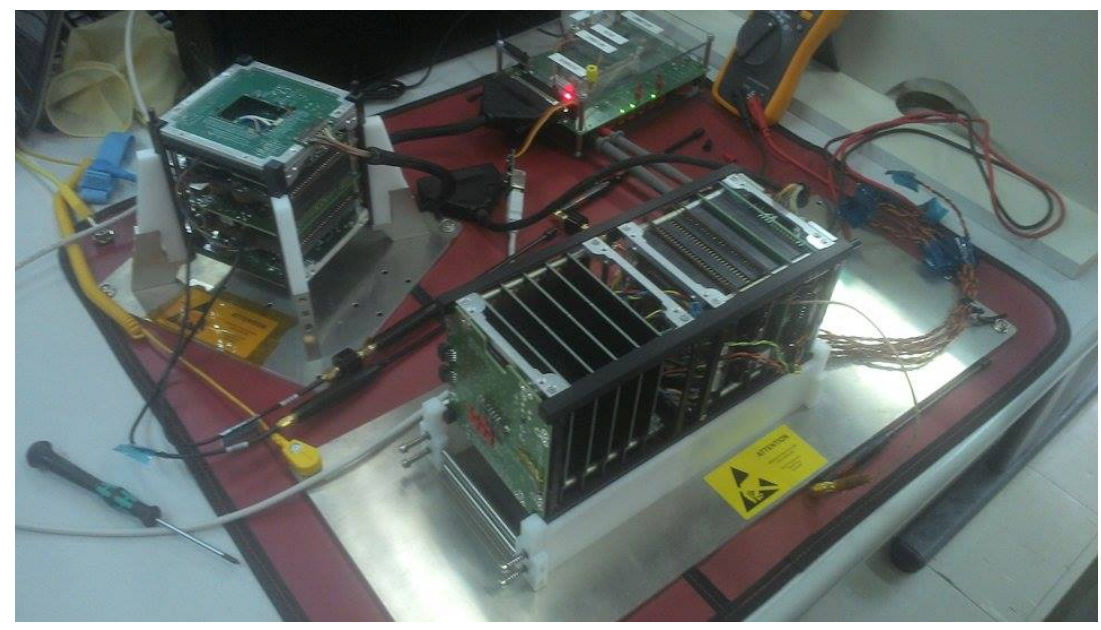

Figure 4 - The NANOSATC-BR1 and NANOSATC-BR2 Engineering Model Platforms.

for space use due to their radiation resistance. The two technological payloads then use two different techniques for fault tolerance due to radiation in space: design (IC) and embedded (software) FPGA. These were the first circuits designed in Brazil for space applications.

\section{NANOSATC-BR1: CURRENT SITUATION}

The NANOSATC-BR1, is a $10 \times 10 \times 11.3 \mathrm{~cm}$ cube, weighing $0.965 \mathrm{~kg}$. Its name and up and down frequencies link were determined by The International Amateur Radio Union - IARU, in 2011.

The NANOSATC-BR1's Engineering Model Platform (EM), the Flight Model Platform (FM), the Ground Support Equipment and the Ground Station for the INPE-UFSM's NANOSATC-BR1 mission and equipment were provided, integrated and pre-tested by the ISIS company from Delft, The Netherlands, except for the integration of the flight model done at the INPE/MCTIC's Integration and Testing Laboratory (LIT). The full Assemble, Integration and Tests (AIT) of the complete CubeSat (platform and payload) were also done at LIT.

The NANOSATC-BR's Ground Station Network (GS) is already installed and in operation: GS(INPE-CRS), at CRS/COCRE/INPE-MCTIC, Santa Maria, RS; and GS(INPE-ITA) at ITA/DCTA-MD, in São José dos Campos, SP, in Brazil (Fig. 5).

The NANOSATC-BR1 was launched as a tertiary payload by ISIS in the event ISILAUNCH 07, by a DNEPR launcher, at The Yasny Launching Base, in The Donbarovsky Region, Russia, on June 19th, 2014 - Launch time (T): 19:11:11 UTC - Local time at Yasny: 01:11.
The NANOSATC-BR1 already completed more than three years in orbit sending payloads and subsystems data. All payloads and subsystems, except the batteries in the power subsystem, continue to operate normally. The battery can no longer hold a charge because it was damaged by magnetic solar storms in September-October 2014. Therefore, the NANOSATC-BR1 can transmit only when it is in sight by the Sun. However, weekly Mr. Reiner Rothe, a german radio amateur and Mr. Paulo Leite (PV8DX), a radio amateur from Boa Vista, RR, Brazil, are performing the NANOSATC-BR1 tracking, downloading and sending systematically these data to the Program's data base, at INPE, in São José dos Campos, SP, in Brazil.

\section{THE NANOSATC-BR1 TECHNOLOGICAL PAYLOAD - THE SMDH-IC RESULTS}

The Santa Maria Design House (SMDH), with design techniques and others considerations, developed Integrated Circuits (IC) for space application regarding Total Ionization Dose (TID): instantaneous radiation dose effects denominated Single Event Effects (SEE) and Displacement Damage (DD). Specific Integrated Circuit (ASIC) was developed for one of the technological payloads of the NANOSATC-BR1 Project. The radiation hardened digital cells designed by SMDH proved a tolerance to solar energetic particles with energies of up to $100 \mathrm{MeV}$.

The SEE tolerance of two shift-registers, with 256 stages and 8 inverters between each chain, is shown in Figure 6 . The blue bar corresponds to the shift registers designed using the conventional digital cells provided by the foundry. On the other hand, the red bars represent the radiation hardened digital cells 

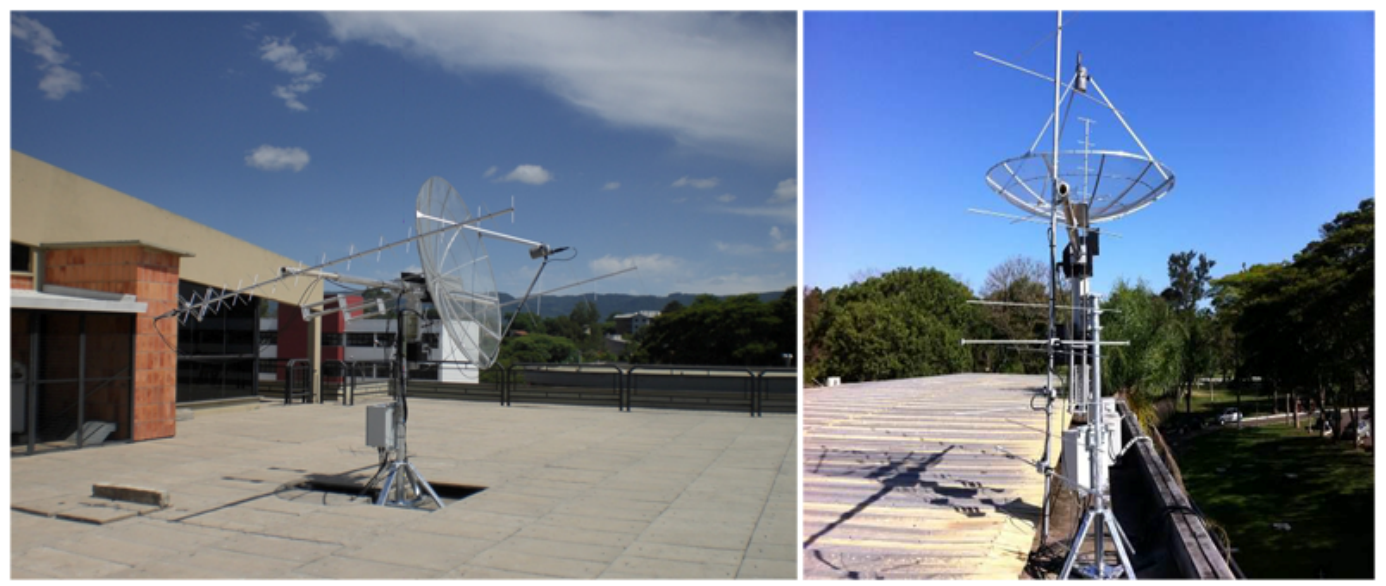

Figure 5 - The NANOSATC-BR's Ground Station Network (GS) was installed and it is in operation: on the left - The GS(INPE-CRS) at CRS/COCRE/INPE-MCTIC, in Santa Maria, RS; and on the right - The GS(INPE-ITA) at ITA/DCTA-MD, in São José dos Campos, SP, in Brazil.

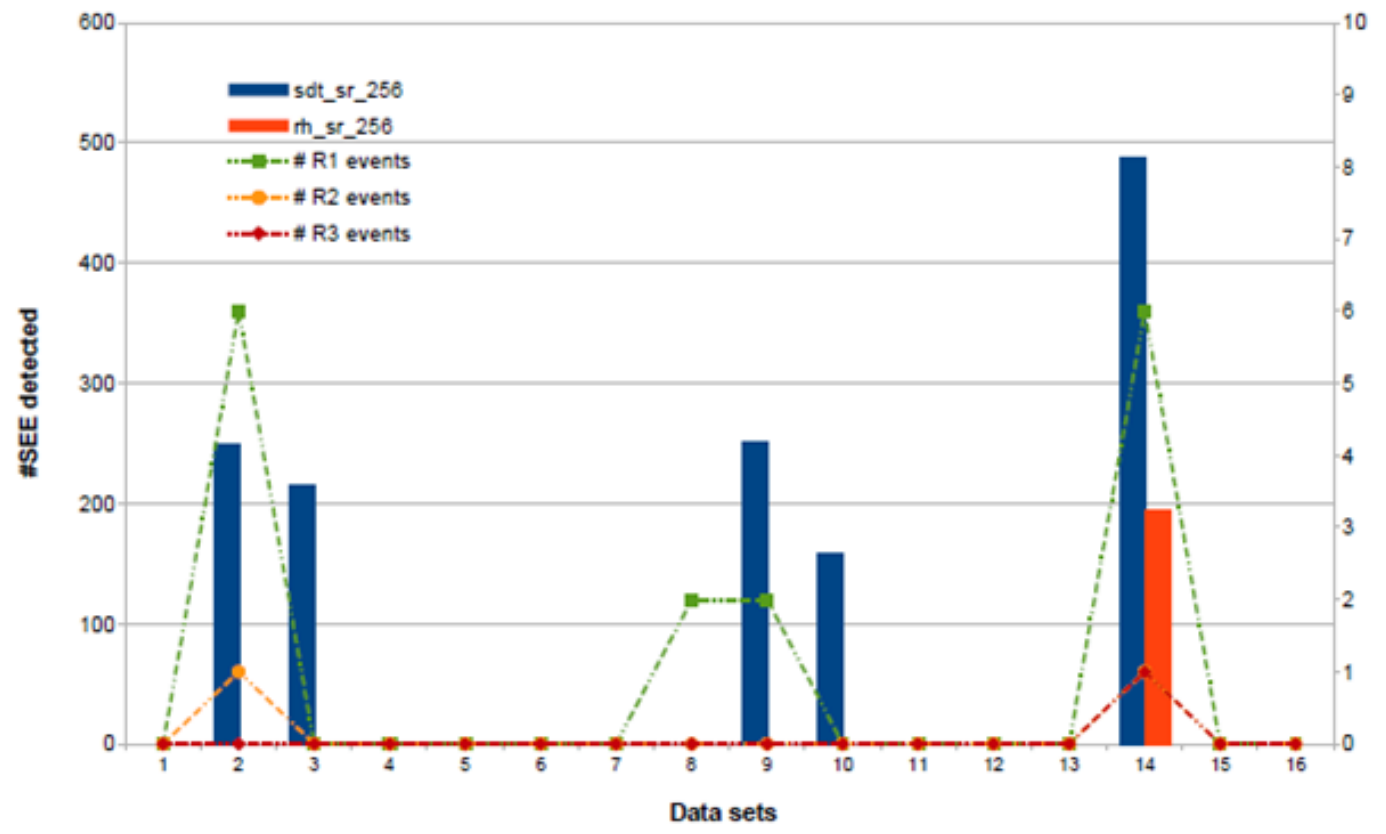

Figure 6 - The NANOSATC-BR1 SEE tolerance comparison of two shift-registers (256 stages, 8 inverters) (Medeiros et al., 2014; Noval et al., 2016).

designed by SMDH. It is remarkable to mention that radiation hardened cells designed by SMDH proved tolerance to SEE with X-rays events of severity R1 and R2 (Noval et al., 2016) - Minor and Moderate Radio Blackouts, respectively. In relation to the R3 event (Noval et al., 2016) - Strong Radio Blackout, the designed cells reported some errors by SEE. The amount of errors in the shift-registers designed using the standard cell library is larger than the shift registers using rad-hard cell library.
The Solar Energetic Protons detected by GOES-15 satellite during September 2014 were used in order to analyze and quantify the energy levels measured during the R3 occurrence and thus estimate the tolerance of customized cells. The fluency of Solar Energetic Protons - SEPs (Medeiros et al., 2014) during September 2014 at different levels of energy is shown in Figure 7. During the first two weeks were reported SEPs with energies above $100 \mathrm{MeV}$. 


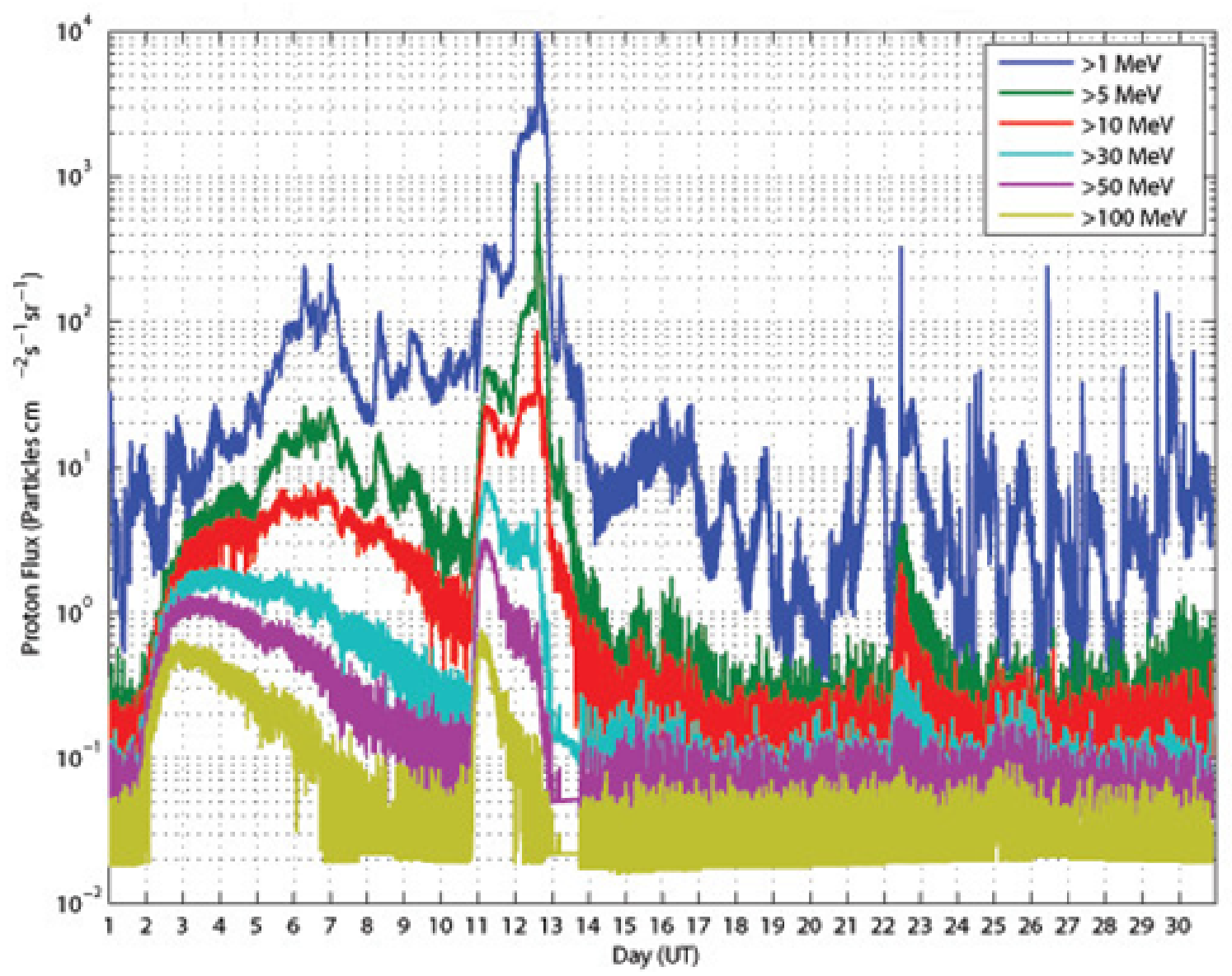

Figure 7 - The Solar Energetic Protons - SEPs detected by GOES-15 satellite during September 2014 (Medeiros et al., 2014)

THE GEOMAGNETIC FIELD INTENSITY RESULTS DETECTED BY THE NANOSATC-BR1 MISSION PAYLOAD

The NANOSATC-BR1 data were collected by the Scientific Mission Payload, which is a XEN-1210 magnetometer. The observations showed an excellent correlation with the theoretical figures for the Geomagnetic Field intensity, given by the International Geomagnetic Reference Field model (IGRF-IAGA/IUGG) in the same altitude. A map of the total intensity of the Geomagnetic Field for an altitude at $614 \mathrm{~km}$ over South America, in the domain of the SAMA (Heirtzler, 2002), is presented in Figure 8. The spatial variation of the total intensity of the Geomagnetic Field varies between $24.000 \mathrm{nT}$ and $17.000 \mathrm{nT}$ at the center of the SAMA, signalized by a black star in Figure 8. The Nanosatellite Earth Tracking and Control Station, GS(INPE-CRS), in Santa Maria - RS, is lying near the center of SAMA. The red line in Figure 5 indicates the approximate orbit of the NANOSATC-BR1 on August 17, 2014, from 10:57h to 11:07h. During this period, the NANOSATC-BR1 moved from South Pole towards to the geographic North Pole.

\section{NANOSATC-BR2: CURRENT SITUATION}

Since the NANOSATC-BR2 is a $2 \mathrm{U}$ CubeSat $(10 \times 10 \times 22.6 \mathrm{~cm})$, it permits a more ambitious mission than its predecessor, the NANOSATC-BR1, with three major objectives: academic and capacity building, scientific mission and technological mission development. The scientific mission is to monitor the Earth's Ionosphere and Magnetic Field. The Ionosphere composition disturbances in the SAMA region over Brazil have severe effects on satellite telecommunications, as well as the precise location with services such as the GPS. The payload equipment for the scientific mission will be a Langmuir probe and a XEN-1210 Magnetic Field sensor based on the Hall effect. The Langmuir probe is normally available in a larger size, however it is being miniaturized for a small satellite mission. 


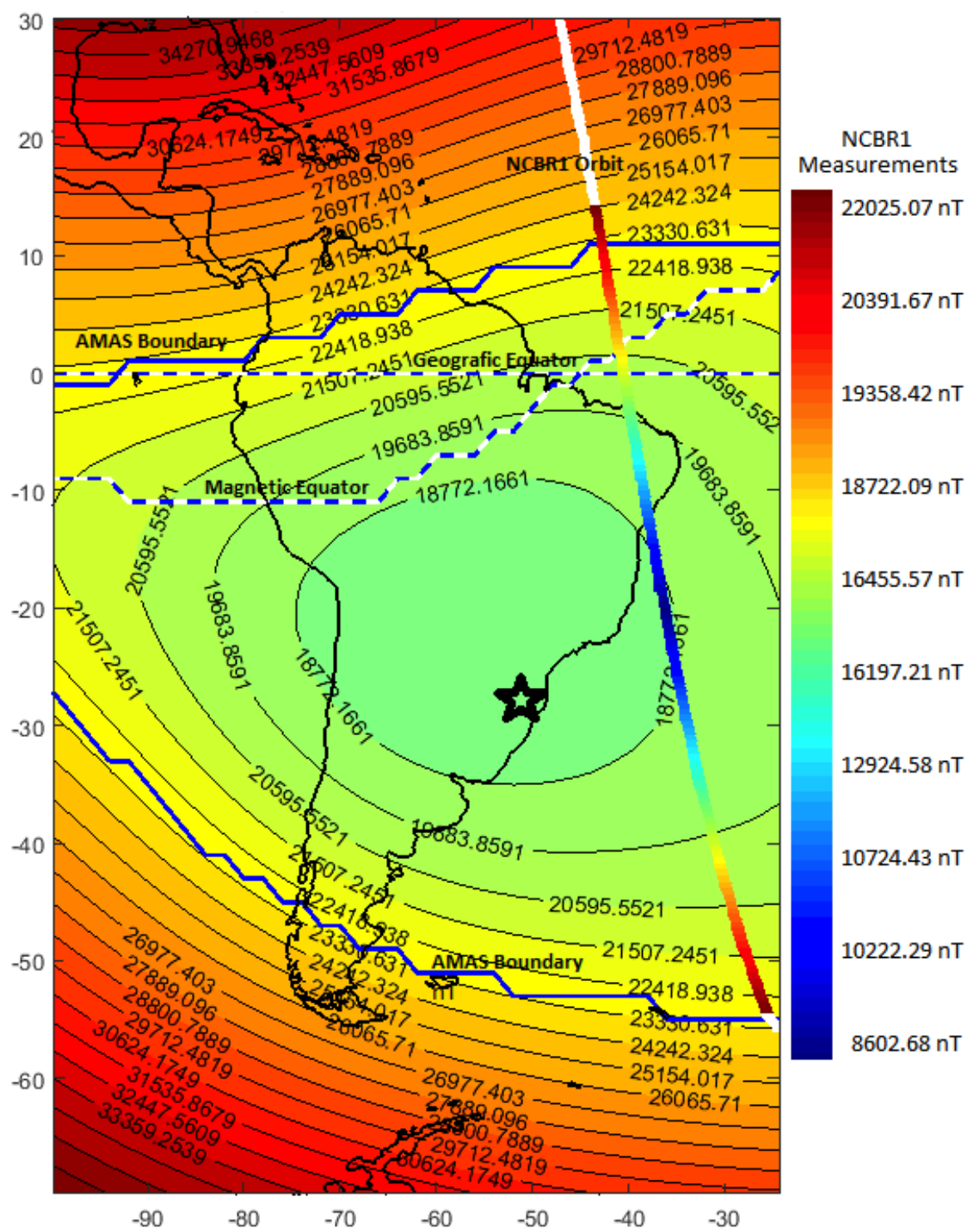

Figure 8 - SAMA Geomagnetic Field total Intensity modeled by the IGRF-10 and NANOSATC-BR1 Scientific mission payload measurements at $614 \mathrm{~km}$ altitude in 2014 for the Geomagnetic Field. The black star indicates the location of the Tracking and Control Station, GS(INPE-CRS), in Santa Maria - RS, which located near the center of the SAMA.

In order to finalize the NANOSATC-BR2, which is now also known by the acronym NCBR2, its platform was developed to satisfy the payload equipment's requirements. The on-board data handling (OBDH) software is a key element for payload integration in NCBR2. It is a software developed at INPE by graduate students of the Space System Engineering Course (INPE/CSE) in collaboration with emergent companies leaded also by INPE's former students. A short Verification and Validation (V\&V) process was defined, addressing the interoperability and robustness issues on the interactions among the $\mathrm{OBDH}$ and the mission payloads (Conceição et al., 2016). Model-based Testing approaches support the integration testing of the communicating software-intensive systems with the use of a fault-Injection mechanism for robustness verification purposes (Almeida \& Mattiello-Francisco, 2017; Batista et al., 2018).

The NANOSATC-BR2 also has the first satellite attitude determination subsystem, fully developed in Brazil, from software to hardware, as one of its experiments. It has triple redundancy 
using three microprocessors with one in hot standby. It's a joint project led by the UFMG with UFABC and INPE. The NCBR2 CubeSat will also carry two other technological experiments as version 2 of those that are flying in NANOSATC-BR1. It also carries an amateur radio communication experiment from Amateur Radio in Space - Brazil (AMSAT-Br) and Brazilian Amateur Radio Broadcasting League (LABRE).

All of those payloads are being integrated and tested with the OBDH software in the Engineering Model (EM), with the exception of the version 2 of the board flying in NANOSATC-BR1, during the final of the integration phase:

- Langmuir Probe - Delivered for testing and integration with the NANOSATC-BR2 EM platform and the on-board software - OBDH;

- Communication Experiment Packet (store forward) AMSAT-BR and SP-LABRE;

- CubeSat board with three experiments - FPGA/UFRGS; Magnetometer; IC/SMDH/UFSM, first unit scheduled for delivery in October 2018.

The entire platform flight software was developed in Brazil, by researchers and engineers from INPE/MCTIC, already working in this area (Attitude Determination \& Control and Data Management), taking advantage of the experience of NANOSATC-BR1; students graduated at INPE/MCTIC on the course of the Space System Engineering (CSE), undergraduate and graduate students and third parties startup company created by former INPE/MCTIC graduate students. The Control Law for the control software has also been developed in house.

The Project has already received the budget from AEB for contracting the launch and future operation of NANOSATC-BR2 in orbit. The NANOSATC-BR2 is expected to be launched in the last quarter of 2019. Likewise NANOSATC-BR1 and other CubeSat projects, the NANOSATC-BR2 will be launched in a piggyback launch, as a tertiary payload. The launch opportunities as well as the Launch Vehicle are under contract.

\section{CONCLUSION}

Since it provides to young people contact with low cost and fast development on Space Technology, the Brazilian: INPE-UFSM, NANOSATC-BR, CubeSat Development Program, proved to be an excellent tool for developing a new generation of Scientists, Engineers and Researchers in Aerospace Technologies in Brazil.

It is expected an increase in the Brazilian Government Agencies support with more investments for the development of Space Technology and new university initiatives. Examples such as the Brazilian INPE-UFSM NANOSATC-BR, CubeSats Development Program, with its two models (the NANOSATC-BR1 \& NANOSATC-BR2 Projects) should be taken into account in this sense.

\section{ACKNOWLEDGMENTS}

The authors thank to the Brazilian Space Agency - AEB, SEXEC/MCTIC, COCRE/INPE-MCTIC, UFSM-FATEC and to USP'S LSITEC Association for the support, opportunity and grants for the Brazilian INPE-UFSM NANOSATC-BR, Cubesat Development Program, with its CubeSats: the NANOSATC-BR1 \& the NANOSATC-BR2 Projects. The authors thank Dr. Juliano Moro and Fernando Sobroza Pedroso for collaboration, to Santa Maria Design House - SMDH/FATEC, to Professors Dr. Ricardo Reis and Dr. Fernanda G. L. Kastensmidt from the Graduate Program in Microelectronics, Informatics Institute from UFRGS, to UFABC (Eng. Aeroespacial - Dr. Luiz Siqueira Filho), UFMG (Eng. Eletrônica - Dr. Ricardo Duarte), the CITAR-FINEP Project, and to MCTIC-CNPq/INPE(PCI-PIBIC-PIBIT) and FAPERGS Programs for fellowships. The authors thank and acknowledge to Eng. Abe Bonnema and the ISIS's Board of Directors for the grant, tutorial and logistics support at Delft, Yasny and Brazil for the Brazilian students and for the NANOSATC-BR, CubeSats Development Program. The Program and NANOSATC-BR1 Project thank to Mr. Reiner Rothe, radio amateur from Germany and to Mr. Paulo Leite (PV8DX), radio amateur from Boa Vista, RR, Brazil, for tracking, downloading and sending systematically these data to the Program's data base, at INPE, in São José dos Campos, in Brazil. Dr. Nelson Jorge Schuch thanks CNPq for the fellowship under the number 300886/2016-0. Dr. Marlos Rockenbach thanks CNPq for the fellowship under the number 301495/2015-7.

\section{REFERENCES}

ALMEIDA DP \& MATTIELLO-FRANCISCO F. 2017. Modeling of the interoperability between on-board computer and payloads of the NanoSat-BR2 with support of the UPPAAL tool. In: 1st IAA Latin American Symposium on Small Satellites. Colombia, Session 9/IAA-LA-09-01. Available on: <http://www.unsam.edu.ar/institutos/ Colomb/Presentaciones/Session.9/IAA-LA-09-01.pdf>.

BATISTA CLG, MARTINS E \& MATTIELLO-FRANCISCO MDF. 2018. On the use of a failure emulator mechanism at nanosatellite subsystems integration tests. In: 19th IEEE Latin-American Test Symposium (LATS). São Paulo, Brazil. p. 1-6. 
CONCEIÇÃO CA, MATTIELLO-FRANCISCO F \& BATISTA CL. 2016. Dependability verification of nanosatellite embedded software supported by a reusable Test System. In: Seventh Latin-American Symposium on Dependable Computing (LADC). Cali, Colombia. p. 157-163.

GUARESCHI WN, SCHUCH NJ, PETRY A, CHARÃO A \& TAMBARA LA. 2010. Analysis of Field Programmable Gate Array Alternatives for use in Nanosatellites. In: 61st IAC, International Astronautical Congress. Prague, Czech Republic: International Astronautical Federation. IAC-10.B4.6B.12.

HEIRTZLER J. 2002. The future of the South Atlantic anomaly and implications for radiation damage in space. Journal of Atmospheric and
Solar-Terrestrial Physics, 64(16): 1701-1708.

MEDEIROS L, ZAFFARI C, NOVAL J, TEIXEIRA L \& MARTINS J. 2014. Using the NANOSATC-BR1 to evaluate the effects of space radiation incidence on a radiation hardened ASIC. In: 1st IAA Latin American CubeSat Workshop. Brasília, Brazil.

NOVAL J, MEDEIROS L, MARTINS J, SCHUCH N, DURÃO 0 \& MACHADO R. 2016. Design considerations for Radiation Hardened ASIC used as technological payload in NANOSATC-BR1. In: 2nd IAA Latin American CubeSat Workshop. Florianópolis, Brazil. IAA-BR-16-0S-OP.

Recebido em 6 setembro, 2018 / Aceito em 28 março, 2019

Received on September 6, 2018 / accepted on March 28, 2019. 